DOI: $\square$ https://doi.org/10.15407/techned2020.01.027

\title{
ANALYSIS OF QUALITY INDICATORS INTO THE PROCESS OF ENERGY TRANSFORMATION DURING DAMPING VIBRATIONS OF ELASTIC MECHANICAL TRANSMISSION BY THE DRIVE
}

Journal

Publisher

ISSN

Issue

Pages
Tekhnichna elektrodynamika

Institute of Electrodynamics National Academy of Science of Ukraine 1607-7970 (print), 2218-1903 (online)

No 1, 2020 (January/February)

$27-32$

\section{Authors}

\section{I.N. Zadorozhniaia*, N.A. Zadorozhnii ${ }^{* *}$}

Donbass state engineering academy,

Akademicheskaia str., 72, Kramatorsk, 84313, Ukraine

e-mail: zadorozhnyaya_in@ukr.net

* ORCID ID : https://orcid.org/0000-0002-7822-3517

** ORCID ID : https://orcid.org/0000-0003-0957-9998

\section{Abstract}

The decision of actual task of taking into account the parameters of the power part of electric drives of technological machines for improving their dynamic qualities is presented at the design stage, which will ensure the specified accuracy of the movement of working mechanisms. It is shown that when choosing the power part of the electric drive to prepare for the synthesis stages of the control system parameters, it is necessary to evaluate the processes of electromechanical energy conversion of elastic mechanical oscillations, which contributes to the maximum of the damping action of the electric drive, and will allow limiting dynamic loads in order to optimize the transient processes. References 13, figure 1, table 1.

Key words: drive, electromechanical system, thyristor converter, damping, oscillations. 
Received: 22.02.2019

Accepted: 04.10.2019

Published: 16.01.2020

\section{References}

1. Kliuchev V.I. Limiting the dynamic loads of the drive. Moskva: Energiia, 1971. 320 p. (Rus)

2. Szabat K., Orlowska-Kowalska T. Vibration suppression in a two-mass drive system using PI Speed Controller and Additional Feedbacks. Comparative Study IEEE Transactions on Industrial Electronics.

2007. Vol. 54. Issue 2. Pp. 1193-1206.

DOI: https://doi

\section{.org/10.1109/TIE.2007.892608}

3. Blagodarov D.A., Kostin A.A., Reznikovskiy A.M., Safonov Yu.M., Chernikov S.Yu.

Development of Control Systems of Electric Drives with Flexible Mechanics. Russian Electrical

Engineering.

2015.

Vol. 86. No 1. Pp. 18-21.

DOI:

https://doi.org/10.3103/S1068371215010058

4. Pyatibratov G.Ya. On the Use of Electromechanical Systems for Limiting Dynamic Loads in Spring Mechanisms. Russian Electrical Engineering. 2018. Vol. 89. Issue 1. Pp. 36-41. DOI: ht tps://doi.org/10.3103/S1068371218010121

5 Bortsov lu.A., Sokolovskii G.G. Automated electric drive with elastic connections. Sankt Peterburg: Energo-atomizdat, 1992. 288 p. (Rus)

6. Kliuchev V.I. Theory of the electric drive. Moskva: Energoatomizdat, 2001. 704 p. (Rus)

7. Zadorozhnii N.A., Zadorozhniaia I.N. Analysis and synthesis of electromechanical drive control systems of machines with elastic mechanical connections. Kramatorsk: DGMA, 2010. 192 p. (Rus)

8. Zadorozhnii N.A., Zadorozhniaia I.N. About mathematical models of thyristor converter of electric drives with elastic mechanical connections. Tekhnichna Elektrodynamika. Tematychnyi vypusk Sylova elektronika ta enerho-efektyvnist. 2011. Part 2. Pp. 206-209. (Rus)

9. Zadorozhnii N.A. Generalized requirements for the design of mechanical gears with elastic connections. Electrical engineering and electrical equipment. 2006. No 66. Pp. 27-29. (Rus)

10. Zadorozhnii N.A., Zadorozhniaia I.N. Interconnections and optimization of parameters for two-mass electro-mechanical systems. Kramatorsk: DGMA, 2015. 202 p. (Rus)

11. Zadorozhniaia I.N., Zadorozhnii N.A. Synthesis of an electromechanical system of the ultimate degree of stability and minimal oscillation of an elastic mechanical subsystem. Bulletin of National Technical University Kharkiv Polytechnic Institute.

2017. No 27 (1249). Pp. 150-155. (Rus)

12. Ivashenko N.N. Automatic regulation. Moskva: Mashinostroenie, 1978. 736 p. (Rus)

13. Zagalskiy L.N., Zilberblat M.E. Frequency analysis of an automated electric drive. Moskva: Energiia, 1968. 112 p. (Rus) 
$\underline{\text { PDF }}$

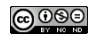

This work is licensed under a Creative Commons Attribution-NonCommercial-NoDerivatives 4.0 International License 